\title{
Cifrando y descifrando el mundo: la Etnoliteratura, una Antropología desde lo literario
}

\author{
LUIS DÍAZ G. VIANA \\ Dpto. de Antropología de España y América \\ CSIC. Madrid
}

\section{RESUMEN}

La relación entre antropología y literatura, así como -más concretamente- entre antropólogos y escritores, parece rica en ejemplos y en asuntos de mutuo interés. Pero no todas son coincidencias: existen también las divergencias propias que se dan entre arte y ciencia, entre cifrar el mundo y descifrarlo. Dentro de ese contexto de múltiples relaciones se reivindica aquí — siguiendo algunas de las propuestas ya realizadas, entre otros autores, por Manuel de la Fuente Lombo- la orientación de la etnoliteratura más que como un subcampo de estudio como una manera de entender el quehacer antropológico: la antropología desde lo literario.

Palabras clave: Etnoliteratura, Antropología, Etnografía, Arte Verbal.

\section{SUMMARY}

The relationship between anthropology and literature, like the more specific between anthropologists and writers, seems rich in both examples and matters of common interest. Yet there are not only agreements between the two realms, but also divergences: those that set apart art from science, coding the world from decoding it. Within this context of multiple interactions, the author follows on some of the proposals advanced by, among others, Manuel de la Fuente Lombo; he advocates an ethnoliterature that is less a sbfield of study than a way of understanding anthropological activity: anthropology from the literary.

Key words: Ethnoliterature, Anthropology, Ethnography, Verbal Art.

RDTP, LX, 1 (2005): 7-41 
Si pensamos en ello, veremos que al plantearnos la pregunta qué es el hombre queremos decir: ¿qué puede llegar a ser el hombre?

O sea, si el hombre puede dominar su destino, puede "hacerse", puede crearse una vida. Decimos, pues, que el hombre es un proceso, y precisamente el proceso de sus actos.

Antonio Gramsci, Antología (Madrid: Siglo XXI, 1974).

\section{ANTROPOLOGÍA Y LITERATURA: EL ARTE DE CIFRAR Y DESCIFRAR EL MUNDO}

\section{Antropólogos y escritores}

En torno al fenómeno de la comunicación unos codifican y otros decodifican el mensaje. También ocurre lo mismo cuando el mensaje es literario, pues la literatura constituye, sobre todo, un acto comunicativo. Pero ¿codificadores y decodificadores son siempre los mismos? ¿Sólo alternan sus roles? No necesariamente. La literatura - si, por ejemplo, se crea y transmite oralmente- da lugar a que el emisor y receptor del mensaje actúen alternativamente sobre la misma materia literaria; sin embargo, lo más habitual es que, en una sociedad aparentemente "letrada" como la nuestra - donde la literatura sigue siendo identificada con lo escrito- el contexto del receptor sea diferente al del emisor. Es decir, que el lector perciba y reinterprete el mensaje del escritor en otro espacio y, casi con seguridad, en otro tiempo e incluso época histórica.

Antropólogos y escritores. Así se nos presentaba en un acto, presentación - a su vez- de libros, al que fui invitado a participar a principios de junio del 2004 y que tuvo lugar en el Museo Nacional de Antropología de Madrid. Un ámbito y ocasión en que, sin duda, la presencia de Manuel de la Fuente Lombo, ya desaparecido en esas fechas y a quien van dedicados estos trabajos, hubiera tenido todo el sentido y mucho que aportar. Pues él se ocupó como pocos —en dedicación y agudeza- de la relación entre lo literario y antropológico. No era el único, desde luego, pues sobre antropología de la literatura y de la literatura o "escritura" etnográfica mucho se ha escrito y debatido en años recientes, pero sí se puede contar a Manuel de la Fuente Lombo - sin exageración algunaentre los más lúcidos estudiosos del tema en España.

De antropólogos y escritores hablamos entonces, en el Museo, como habíamos charlado largamente Manuel y yo en el último Seminario sobre Etnoliteratura que él organizó en la Universidad de Córdoba. Y siempre que se aborda este asunto, surge o puede surgir en muchos la pregunta: ¿qué tienen que ver antropología y literatura entre sî́? ¿arte y ciencia, si preferimos palabras aún mayores? ¿poco, nada, mucho? Dependerá, desde 
luego, de los casos, de las obras concretas de antropólogos y escritores de que estemos hablando. Es evidente que, si nos centramos en los libros de Enrique de Hériz y Albert Sánchez Piñol que se presentaban en aquella circunstancia, tal relación existe y, además, parece suficientemente relevante.

Escritores y antropólogos coinciden en los espacios de la comunicación literaria.

A veces, hasta parece que hicieran la misma cosa. Y que no sólo se dedican a lo mismo, escribir, sino que - también - son o pueden ser las mismas personas.

\section{La inevitabilidad del mito: ¿cómo saber de los hombres cuando no bay "textos"?}

De otro lado, a menudo vemos quienes nos dedicamos a la antropología social y cultural profesionalmente que, desde una disciplina emparentada con la nuestra, que goza hoy de mayor fama y fortuna - hay que reconocerlo- y que se supone tan poco dada a veleidades literarias como la paleoantropología, se nos cuenta la evolución del hombre como un relato mítico. Los huesos rescatados de un sueño de miles de años terminan siendo un mito del progreso, tal como se nos cuenta en series divulgativas de televisión. Algunos antropólogos culturales, sin embargo, hace tiempo que entendimos que los mitos pueden enseñarnos tanto $o$ más que los huesos. Pueden encerrar tanta o más verdad sobre la identidad humana que ellos. O, en todo caso, llegamos a pensar que la literatura de los viejos mitos de la humanidad —que aún viven entre nosotros- no es menos "verdad".

Porque de lo que se trata, al fin y al cabo, es "de dotar de una imagen vital las formas de vida de nuestros antepasados" (Ortiz 2001: 289) e incluso las de la vida de nosotros mismos. La respuesta a la pregunta que se hace Ortiz de por qué la prehistoria y la etnología que se han practicado en España generalmente no lo han conseguido resulta ardua y -probablemente por ello- es contestada con otra interrogación: "no está en los cráneos, pero ¿está en las piedras?» (Ortiz 2001: 289). Y puede que esté, también, en la manera en que paleoantropología y prehistoria han dado la espalda a la antropología en nuestro país. Se habla, así, del origen del hombre, cuando para precisarlo sería necesario explicar qué es lo humano o a qué consideramos como tal. Algo que pertenece al campo de estudio de los antropólogos. Pues para contestar qué es y cuáles son las formas en que lo humano se manifiesta hay que recurrir a lo que los hombres se han contado o, mejor, cómo se han contado en sus obras. 
Podrá decirse que al tratarse de épocas de las que no existe memoria escrita ello no resulta posible. Sin embargo, hay una continuidad en los hombres y vestigios de ellos que nos narran su pensamiento - como pueden ser las pinturas y utensilios-, aun antes de que existiera la escritura. Y la posibilidad - siempre resbaladiza, aunque real— de compararlos (más que de identificarlos) con grupos humanos que todavía conservan mucho de las formas de vida primitivas. Comparación que guió —como es bien sabido- los pasos de algunos de los primeros practicantes de la antropología, a pesar de que antropólogos posteriores señalaran que, algún tiempo después, "no se iba, ya, al trabajo de campo para buscar formas antiguas de vida humana, sino otras diferentes a las que conocíamos" (Mead 1987: 136). Se había hecho durante muchos años, como este mismo texto refleja y eso es lo que, aquí, parece pertinente destacar. Pues todo ello parece ahora haberse olvidado, y - en su defecto- es la ciencia de los cráneos la que intenta contar, desde cero, lo que hacían y pensaban quienes estaban alli dentro. El resultado es pobre. En ocasiones, excesivamente burdo. Recuerda a un cómic por el poco “texto"; a un tebeo - a veces demasiado optimista y esquemático- que estuviera principalmente encaminado a hacer resaltar los logros evolutivos de lo humano.

Retomando la cita inicial de Gramsci, podría decirse que el hombre es tanto el proceso de sus actos como el de sus invenciones; de lo que es y no es, pero se cree y quiere ser. Que lo humano no reside sólo en el tamaño de los huesos ni en la evolución de nuestra rabadilla. No ha sido únicamente el lenguaje, ni la posibilidad de elección, la opción de hacer esto o lo otro, de distinguir y discernir, ni siquiera la conciencia de nosotros mismos, lo que nos ha hecho humanos. Ha sido probablemente más la conciencia de lo que no somos, de lo "otro" y de los "otros", y el no renunciar a apropiárnoslo, a imitarlo hasta hacerlo nuestro, a absorberlo mediante imágenes, símbolos, gestos, palabras y —en definitiva- ritos, lo que nos hizo así. No fue nuestra conciencia, sino más bien nuestro delirio, lo que nos ayudó a cambiar. La capacidad de inventarnos e inventar. El hombre es hombre porque resulta capaz de vivir lo imaginario como real.

\section{De los antropólogos como autores}

Alberto Cardín, tan antropólogo como escritor él mismo, me encomendó, hace ya unos cuantos años, escribir la introducción del libro Writing Culture (1984), titulado en español Retóricas de la antropología (Clifford y Marcus 1991), que además de convertirse en uno de los libros emblemáticos de la mal llamada antropología postmoderna, trataba entre otras 
cosas -al igual que la obra de Geertz, El antropólogo como autor (1989), con la que casi viene a solaparse en fechas de publicación en Españade cómo se "escribe la cultura" o, dicho de otra manera, de cómo escriben los antropólogos. De los antropólogos como escritores.

Uno mismo ha dirigido durante algunos años una colección que se llamaba precisamente así, Antropología y Literatura. La relación implícita en ese título, según he podido ir constatando a lo largo del tiempo, más que una casualidad es una constante. Antropólogos y escritores no están tan lejos como pudiera pensarse. A veces, e incluso a menudo, se confunden en su interés por reflexionar sobre lo humano, por descubrir la "Sustancia cultural" de lo que entendemos por humanidad. Escritura y antropología se entremezclan, sí, empezando por los propios antropólogos. No sólo porque, como viene a decir Geertz - de una manera que suena casi a obviedad - en su libro citado, los antropólogos (en cuanto a autores que son) fundamentalmente escriban (Geertz 1989). Escriben, en efecto, pero no sólo antropologías, sino también -y mucho- literatura. De modo privado e íntimo, como Margaret Mead hacía con sus parejas o su hija Katherine y -muy especialmente- con el también antropólogo Gregory Bateson, intercambiando poemas, y —de modo más público- escribiendo memorias que, en el caso de la propia Mead o de nuestro Julio Caro Baroja en su libro Los Baroja (1972), se convierten en otra forma de hacer antropología. La antropología de uno mismo y de su entorno. Y hay quien, de hecho, piensa que esta obra de Caro es también su mejor obra antropológica.

Escriben los antropólogos, en efecto, dejando que literatura y antropología se contaminen, como Lévi-Strauss en sus Tristes Trópicos (1988). Ya mencionaba Margaret Mead en Experiencias personales y científicas de una antropóloga, refiriéndose a sus compañeros y a ella misma en sus tiempos de estudiante, que aescribíamos poesía con la misma intensidad que trabajábamos en antropología" (Mead 1987: 122). Conozco en la actualidad, igualmente, a muchos colegas españoles que escriben literatura, ya mencioné antes al desaparecido Alberto Cardín que era un excelente ejemplo de capacidad en ambos quehaceres. Y hasta podría decirse, también, leyendo a ciertos autores - como Sánchez Piñol, quien presentaba su libro en el acto del Museo al principio mencionado-, que quizá algunos interesantes textos muy cercanos a la antropología se estén escribiendo en nuestro país - formalmente al menos- fuera de la antropología académica. La etnografía que este novelista -antropólogo de formación- escribió finalmente sobre su frustrado y - seguramente- frustrante trabajo de campo, se llama La piel fría (2004) y recuerda a los cuentos de Lovecraft más que a las rotundas descripciones - casi siem- 
pre caracterizadas por camuflados asertos incomprobables- de un EvansPritchard. Algo, esto último del estilo sofisticadamente afirmativo de Pritchard, sobre lo que Geertz escribió con implacable afán deconstructor:

Los presupuestos que conectan al autor con su público, presupuestos que son a la vez sociales, culturales y literarios son tan fuertes, e impregnan todo de tal modo, están tan profundamente institucionalizados, que las menores señales pueden vehicular enormes mensajes (Geertz 1989: 68).

Lo que no debe ser entendido como que —en opinión de GeertzSir Evans-Pritchard no escribía bien, sino que lo hacía de la mejor manera posible para persuadir al lector de su objetividad y autoridad científica.

\section{Realidad y ficción: las invenciones de lo exótico}

Pues ¿dónde empiezan y acaban lo uno y lo otro, lo antropológico y lo literario? Dirían algunos, los más exigentes y cientifistas, que hay una frontera donde acaba la verdad y empieza la ficción. Donde acaba, quizá, la antropología y empieza la literatura. El protagonista de La piel fría de Sánchez Piñol dice que aunque los hombres tenemos tendencia a echar la culpa de nuestras penas a las grandes hecatombes -eso realza nuestra importancia como individuos-, la verdad casi siempre se escribe en minúsculas" (Sánchez Piñol 2004: 196). Y la antropología suele ocuparse - precisamente- de las minúsculas en el texto de la cultura. Pero si ni siquiera Jesús de Nazaret respondió a la filosófica pregunta de Pilatos sobre lo primero ("qué es la verdad?") — tal como nos lo cuentan los evangelios, testimonio de la verdad cristiana, pero sobre todo obra literaria-, menos se podría contestar satisfactoriamente a lo segundo: ¿qué entendemos por ficción? Una novela se supone que es ficción y unas memorias no. Sin embargo, sabemos que las buenas novelas suelen hacerse con fragmentos de realidad, de sensaciones y experiencias vividas, y que las memorias con frecuencia son un género mentiroso, donde el que las cuenta suele estar demasiado preocupado por quedar bien él y - si se puedeperjudicar a otros como para ocuparse rigurosamente de la verdad.

Leyendo las dos novelas que se presentaban aquella tarde de verano en un museo madrileño, la sensación de "verdad" es grande y debo decir -incluso- que la impresión de lo vivido en La piel fría, que parece la más fantástica (casi una parábola sobre lo humano y lo inhumano) no resulta menor -aunque por el tema pudiera antojársenos menos verosímil- que en la otra o algunas narraciones de convencional tono realista.

Ha escrito Joan Marsé sobre el otro libro presentado en el acto, Mentira (2004), de Enrique Hériz, que "Esta Mentira abre senderos y abismos 
que sólo la novela puede transitar" (Hériz 2004: cubierta). Yo me atrevería a añadir que novelas como ésta se adentran en el territorio de los mitos y los ritos con el bagaje o la mirada que sólo pueden proceder de la antropología. Porque hay momentos en que el profesional de la etnografía no puede hablar de todo lo que necesita expresar en una monografía y se pasa abiertamente a la literatura; y otros en que - tambiénlos escritores recurren al saber antropológico como referencia e inspiración. Entonces, los antropólogos escriben casi como el novelista, sin dejar de ser antropólogos, del mismo modo que cuando escriben etnografías no pueden ni deben dejar de escribir bien. Los que pueden. $\mathrm{Y}$ algunos de los más grandes, como Tylor, Frazer, Lévi-Strauss, Evans-Pritchard, no lo hacían tan mal. El novelista que lo es habla de la verdad mediante ficciones. Los antropólogos han evocado verdades hasta persuadirnos, en más de una ocasión, de la ficción:

Los primeros antropólogos que visitaron las islas -escribe Hériz- no daban crédito a lo que veían. Al regresar escribieron artículos en revistas especializadas para dar noticia de su descubrimiento. En textos densos y sembrados de hipótesis imaginativas, afirmaban haber encontrado una comunidad que manifestaba ante la muerte de sus miembros sentimientos mucho más profundos y auténticos que cualquier otra (Hériz 2004: 23).

El etnógrafo en busca de la exótica autenticidad. El folklorista tras la búsqueda de lo auténticamente tradicional. El etnógrafo como involuntario o - a veces- no tan involuntario inventor de exotismos, de autenticidades que puedan ser después explotadas por el turismo ávido de consumir nostalgias. Hasta que cualquier rastro de esa supuesta autenticidad desaparezca cuando todo se llene de visitantes ociosos con sus cámaras. Porque iha inventado la antropología mundos felices, paraísos exóticos a partir del estudio de los que se pensó eran salvajes inocentes como niños o primitivos contemporáneos? Probablemente en más de una ocasión sí, se tratara de salvajes de fuera o de dentro, de "prelógicos" indígenas o de "atrasados" campesinos.

Las interpretaciones dadas, por ejemplo, por Derek Freeman en un libro que suscitó gran revuelo y debate antropológicos, componen, respecto a lo antes escrito por Mead sobre los samoanos, un díptico en torno a la ambivalencia del mundo occidental frente a los primitivos. Ambas visiones, idealizadora la de Mead (1928) y pesimista la de Freeman (1983), serían -en definitiva - alegorías que nuestro mundo proyecta sobre los otros. Mead vio en Coming of Age in Samoa - libro traducido al español con el más impactante título de Adolescencia, sexo y cultura en Samoa (1984) - un modelo de libertad a imitar o a trasplantar a los USA en el 
comportamiento "liberado" que las adolescentes samoanas tenían —según ella- respecto al sexo. Freeman, más de 50 años después, pensó que Mead había exagerado, atendiendo más al cambio de modelos de conducta en su país (y contribuyendo a ello) que a lo que realmente era el comportamiento de las chicas de Samoa. Ya advirtió la propia Mead - pero seguramente no se refería a sí misma- que "cuando tratamos lo que es nuevo como una variante de algo ya conocido es posible equivocarse enormemente" (Mead 1987: 138). A lo mejor, simplemente había pasado demasiado tiempo como para establecer comparaciones válidas. ¿Vio Mead lo que quería ver? ¿Inventó lo que quería que pasara? ¿Encontró —o creyó encontrar - lo que ella misma en su vida estaba buscando?

\section{Sobre los modos de cifrar y descifrar la experiencia}

Son quienes presentaban sus libros en aquella citada reunión del Museo de Antropología escritores que, con frecuencia, parecen pensar como antropólogos. Antropólogos cuando razonan y escritores cuando escriben. La literatura y la novela —que, quizá, lo bueno que tiene es que se trata de un género en el que parece caber todo- se enriquecen con ello. Algunos autores de nuestra disciplina han señalado ya, en distintas ocasiones, una máxima paradoja de la antropología: defender y asentar como principio universal que todos los hombres tienen algo en común, la cultura, y asumir que, a su vez, es ésta lo que nos diferencia, pues todas las culturas son diferentes modos de ver y nombrar el mundo.

En la contracubierta de La piel fría se nos cuenta que es éste un libro que "nos obliga a replantear no sólo nuestra mirada sobre el mundo, sino, sobre todo, hacia lo exterior, lo ajeno, lo extrañom. No caben muchas definiciones mejores de aquello para lo que sirve - mejor que cualquier otra disciplina - la antropología y, a menudo, la propia literatura. Por lo menos las que a mí me interesan. Y es que antropología y literatura son caminos privilegiados para indagar en el conocimiento de lo humano, más allá de los etnocentrismos y mentiras $\multimap$ interesadas verdades- a las que nos acostumbraron durante mucho tiempo ciertas maneras occidentales de entender la filosofía y la historia. Comentaba Caro Baroja refiriéndose a él mismo como antropólogo que, a menudo, desde la antropología desandamos caminos que el arte ya había recorrido (Caro Baroja 1979): decodificamos lo codificado. Quizá estribe en ello la más importante diferencia entre el creador o escritor y el autor humilde, pero no menor, que -con frecuencia y casi inevitablemente- termina siendo el propio antropólogo.

Sí, los antropólogos escriben —como decía Geertz-. Y algunos muy 
bien, además. Pero, según apunta el mismo autor, "argüir que la escritura etnográfica implica contar historias [...] es algo que encuentra resistencias, a menudo feroces, debido a la confusión, endémica en Occidente desde Platón, entre lo imaginado y lo imaginario, la ficción y lo falso, entre producir cosas y falsificarlas" (Geertz 1989: 50).

Cabe puntualizar: hay novelistas que se plantean problemas muy parecidos a los de los antropólogos, aunque los traten y escriban de otra manera. No olvidemos que "la incapacidad de las psicologías y filosofías más convencionales para explicar la extraña conducta de los paganos y los locos fue el principal factor - como ha escrito Kluckhohn - que obligó a la psiquiatría y a la antropología a desarrollar teorías del inconsciente y de la cultura" (Kluckhohn 1983: 34). Y que muchas obras literarias nos habían precedido en identificar lo que Augé ha descrito, en El genio del paganismo, como parte sustancial del quehacer etnográfico: aprehender "el arte, el gesto, la belleza, la palabra silenciosa de los otros" (Augé 1993: 15).

Resumiendo: el escritor como gran codificador y el antropólogo, tanto o más que como autor —que también-, como lector que reinterpreta, como decodificador de lo ya cifrado, fuera quien fuera el cifrador de historias y su calidad o profesionalidad literaria.

El antropólogo como reinventor de la realidad.

\section{LA ETNOLITERATURA: ¿UN NUEVO MÉTODO DE ANÁLISIS ANTROPOLÓGICO? \\ 1. El término de "etnoliteratura"}

Este término parece remitir, en primera instancia, a una etnología de la literatura o a un estudio de las literaturas de las distintas "etnias" y culturas ligadas a ellas. Digo etnología y no, todavía, antropología de lo literario, con toda consciencia, recordando de paso - como hace Alfredo Jiménez Núñez (1994) en un trabajo al respecto- que hubo una época no tan lejana en que los antropólogos - principalmente los funcionalistasse esforzaron en distinguir la antropología de la etnología. Es decir, la antropología que ellos querían hacer de la versión historicista de lo antropológico que se había venido practicando hasta ese momento y a la que identificaban con el término de etnología. Dice este autor:

Lo evidente es que Radcliffe Brown $-\mathrm{y}$ no puede olvidarse el prestigio y la fuerza que tuvieron sus ideas durante bastante tiempo- consideraba dos cosas muy diferentes la "antropología social" y la "etnología", que a esta última la consideraba una forma de historia y no una ciencia, mientras que pretendía aproximar todo lo posible la primera al carácter experimental, comparativo, riguroso y generalizador que es propio de las ciencias naturales o, simplemente, de la ciencia. En otras 
palabras, los presuntos ataques de Radcliffe-Brown no lo fueron tanto a la historia como a lo que él entendía por etnología (Jiménez Núñez 1994: 18).

Hay -incluso- quienes, todavía, más allá de esta distinción y aparentes oposiciones del pasado, tienden a enmarcar - hoy - la etnoliteratura dentro de la etnohistoria, a modo de rama de especialización que quedaría comprendida por aquélla y a considerarla como método (si no como disciplina o subdisciplina) que entienda la pura obra literaria como contenido y fuente para la antropología. Ha escrito, así, en este sentido, Manuel de la Fuente Lombo:

\begin{abstract}
La etnoliteratura surge como una variable diferenciable pero no separable (al menos necesariamente) de los otros modus operandi del antropólogo; presenta, en nuestra opinión, unos significativos lazos de parentesco con la Etnohistoria, no sólo por la parcial (de parte) identificación nominal —que puede ser algo secundario-, sino porque se origina también en el discurso escrito como herramienta de trabajo, en este caso la experiencia literaria, y, sobre todo, porque de forma semejante a la Etnohistoria, el documento escrito le interesa como exponente de la relación entre el escritor y su invención de la realidad (Fuente Lombo 1994: 57).
\end{abstract}

Sin embargo, ambas aproximaciones a la etnoliteratura - la de etnología literaria y la de parte de la etnohistoria - contribuyen a connotarla de rasgos que, quizá, no son los que mejor podrían servir para definir o caracterizar al estudio de lo etnoliterario en la actualidad. Ya sea porque no se corresponden del todo con los propósitos de quienes reivindican el término como una deseable, pero no muy empleada, metodología de la práctica antropológica, ya sea porque - según me propongo exponer aquí- limita la dimensión de sus posibles objetivos.

\title{
2. Etnografía, etnología y antropología
}

De un lado, la etnología constituyó en el pasado una forma teórica e histórica de hacer antropología que pretendía, mediante el estudio de los llamados "primitivos contemporáneos", pero también de las civilizaciones históricamente conocidas, reconstruir los distintos pasos de evolución de la humanidad. Ello la aproximaría, en lo teórico, a posiciones identificadas con el "evolucionismo cultural" y, en la práctica, a desarrollar - preferentemente- etnografías de los pueblos colonizados. Aunque la etnología sea considerada, en la actualidad, más como una fase de las actividades del etnógrafo que como disciplina aparte o independiente de la antropología, se halla aún cargada de resonancias que aluden al método comparativo.

Sería, así, la etnología ese estadio del trabajo del antropólogo en que las descripciones etnográficas son sometidas a comparación y contraste, rela- 
cionadas con aspectos similares de otras culturas o de la cultura propia, antes de que podamos proceder a cualquier intento de interpretación.

Reproduzco en este apretado resumen, arriba apuntado, el conocido - $\mathrm{y}$, en general, aceptado- esquema de acuerdo con el cual los componentes de la tríada etnografía-etnología-antropología constituirían a modo de etapas del trabajo cabal del antropólogo, lo que haría además innecesaria - si no tendenciosa - la pretendida distinción entre etnógrafo-etnólogoantropólogo: es decir, que habría un primer paso en que se recogen datos y se hacen descripciones de lo que se pretende estudiar (etnografía), un segundo en que se compara el material recopilado con otros semejantes - por el problema, sujeto, tema u objeto estudiables- (etnología), y un tercero en que todo ello es analizado con la pretensión de construir un modelo interpretativo (antropología). Y, si bien hay autores que obvian la distinción entre todos estos términos, o quienes han utilizado la denominación de etnología para referirse preferentemente a los "clásicos" de la historia de la disciplina, suele aceptarse en los tratados y diccionarios antropológicos más al uso la gradación diferencial entre etnografía, etnología y antropología que señalaron, ya, etnólogos-antropólogos de prestigio, como Lévi-Strauss:

En relación a la etnografía, la etnología representa un primer paso hacia la síntesis. Sin excluir la observación directa, tiende a establecer conclusiones suficientemente extendidas en tres direcciones, geográfica, histórica y sistemática [...] mientras que la Antropología intenta dar un conocimiento general del hombre abarcando en toda su extensión la historia y la geografía, aspirando a un conocimiento aplicable al conjunto del desarrollo humano desde las sociedades más primitivas a las más modernas (Lévi-Strauss 1963: 355-356).

Y, así, en uno de esos Diccionarios - a los que antes he aludidopuede también leerse, en palabras de $\mathrm{M}^{\mathrm{a}}$ Jesús Buxó, la siguiente clarificación entre términos:

La Etnología aporta una complejidad teórica adicional relativa al interés por sistematizar la clasificación y comparación entre las similaridades y diferencias entre las variables de diversas culturas, o de diferentes periodos históricos, lo cual requiere que el etnólogo desarrolle sus propias teorías e interpretaciones de los datos etnográficos. Estas categorías ofrecen una base uniforme para la comparación, aportan contrastes que deben ser explicados, y sugieren relaciones entre diferentes formas culturales. Y, a partir de todo este proceso, se trataría de llegar a la concreción antropológica que por simple etimología, supone explicar o interpretar la cultura humana en su doble dimensión universal y particular (Buxó 1993: 277).

Vemos, pues, que esa cierta confusión (e incluso contradicciones) en el uso de unos u otros términos que, a veces, parece surgir para referirse 
al quehacer antropológico, es —en lo esencial- bastante aparente. Pero nos interesa ahora reconsiderar por qué algunos autores siguen prefiriendo la utilización de la denominación etnología para referirse a los "clásicos" de la antropología o, mejor, a una forma pretendidamente clásica de hacer antropología que relaciona a las diversas culturas para averiguar cómo han llegado a ser como son. Fue, precisamente, Lévi-Strauss quien señaló que, a partir de un determinado momento —que puede datarse en relación con el advenimiento del funcionalismo-, gran parte de los antropólogos renunciaron (en aras de la aplicación de un análisis sincrónico) "al entendimiento de la historia" y a la comprensión de "cómo las cosas habían llegado a ser" (Lévi-Strauss 1963: 9).

Dado que el uso del término antropología se volvió en una determinada época, con el adjetivo de cultural o social añadido a ella, bastante restrictivo, quizá convenga recordar que, al quedar algo relegado el nombre de etnología como ligado a una etapa ya superada de la historia antropológica o quedar éste subsumido en antropología, se perdió cierta orientación ambiciosa y comprehensiva en el conocimiento de lo humano que, en sus inicios, había pretendido tener la disciplina. Y destacar, de otro lado, que -además - en ocasiones la etnología se redujo a mera etnografía o recolección de descripciones etnográficas.

Etnologia, etnografía y antropología suelen utilizarse -en la práctica- muchas veces también como sinónimos, pero lo cierto es que en un montón de manuales se sigue haciendo la distinción a la que me he referido en principio. Varios institutos - especialmente europeos- que se denominan como de etnología o etnológicos están dedicados, en la actualidad, al estudio de las culturas populares respectivas y, de otra parte, en algunos ámbitos antropológicos - como el anglosajón- etnógrafo y antropólogos son términos empleados casi indistintamente. No así en otros lugares - como España- donde hay casos de quienes prefieren llamarse sólo etnógrafos e incluso parecen rechazar con ello los aspectos analíticos e interpretativos que la antropología tiene, como si identificaran a la etnografía en sí misma con la ciencia verdaderamente empírica y redujeran ambas (etnografía y ciencia en general) al mero acarreo de datos.

No estaría —quizá- de más recuperar, en el momento presente de la antropología, esa otra orientación más amplia de la etnología -lo que también puede explicar que antropólogos como Lévi-Strauss siempre se hayan sentido más cómodos siendo identificados como etnólogos- para devolver a la antropología su primigenio sentido y conferir al término etnoliteratura un enfoque paralelo, en lo teórico y en lo metodológico. El de ocuparse de lo humano en el tiempo y el espacio, ordenando, comparando e interpretando, en el caso de la etnoliteratura a partir de 
fuentes literarias tanto orales como escritas, lo que sabemos o pretendemos conocer de lo humano.

2. La etnoliteratura: ¿nuevo método de análisis, nueva subdisciplina u otra manera de hacer antropología?

De otro lado, los autores que -como Manuel de la Fuente Lombohan revindicado la etnoliteratura (y el uso del término) en cuanto a "nuevo método de análisis antropológico" (Fuente Lombo 1994: 51-72) ponen el énfasis en la relación de antropología y literatura como una confluencia fecunda y necesaria que ampliaría la metodología antropológica de uso más frecuente. Una conexión que, además, viene de lejos - a pesar de que ese método de análisis situado bajo la advocación y amparo de la denominación de etnoliteratura se reclame como "nuevo" - ya que, según tales estudiosos recuerdan, algunos antropólogos del ayer habrían apuntado el interés de las fuentes literarias (no sólo de carácter histórico) como objeto de investigación de esta disciplina.

Se cita, en este sentido, por ellos, lo que dejó escrito y dicho Julio Caro Baroja, dentro de la tradición etnográfica española, al respecto. Ya que manifestó éste, en varias ocasiones, cómo la antropología no debería desdeñar la potencialidad de algunas obras literarias en cuanto a caudal de información etnográfica, refiriéndose, tanto a los escritores del Humanismo - así Rodrigo Caro- y de nuestro Siglo de Oro - Lope de Vega, Cervantes y, muy en especial, los autores de novela picaresca-, como a otros más recientes, entre los que estarían Jovellanos, Blanco White o Estébanez Calderón (Caro Baroja 1967: 11).

La conexión de la literatura con la antropología es un fenómeno que habría que estudiar mucho más intensamente de lo que hemos hecho. Pienso, por ejemplo, que en el Renacimiento o en el Siglo de Oro español, y en otras muchas literaturas del mundo, muchos escritores se han planteado temas antropológicos. Muchos de los trabajos que han realizado estos escritores aportan material importante, y no pueden ser desdeñados por el antropólogo o por el sociólogo. Cuando uno lee Rinconete y Cortadillo y ve el análisis que hace Cervantes de una sociedad de maleantes del siglo XVI en Sevilla, y se observa cómo dibuja el escritor la vida de esos maleantes, piensa que eso no será antropología criminal, ni tendrá que ver con lo que hicieron los teóricos italianos del siglo XIX, pero el material ahí está, y la observación también (Caro Baroja y Temprano 1985: 53-54).

Pero no sólo aludió Caro a creadores españoles de ficciones literarias, sino también a otros foráneos del ámbito de la pintura:

Los aspectos estéticos, emocionales y pasionales en la vida popular tienen una importancia acerca de la cual conviene hacer hincapié y ellos solos explican la 
significación constante de lo folklórico en la Literatura y en el Arte. ¿Qué folklorista profesional puede presumir de haber interpretado la vida del pueblo mejor que un pintor como Bruegel el viejo? (Caro Baroja 1967: 11).

Se ha señalado, además, en más de una ocasión - y por diversos autores- el valor de otras fuentes histórico-literarias, como son las Crónicas de Indias y textos asociados a ellas, así Los Comentarios Reales del Inca Garcilaso de la Vega o incluso la obra poética de Alonso de Ercilla, La Araucana. Escribe - en este sentido- Alfredo Jiménez Núñez, con toda pertinencia, que "la América española ofrecía unas posibilidades que la historia no había explotado suficientemente y la antropología había ignorado [...] ninguna historia colonial contaba con la riqueza y diversidad de fuentes documentales que poseemos para la América española por razones que tienen que ver con la propia sociedad y cultura dominante" (Jiménez Núñez 1994: 20). Y ello tanto porque contamos no sólo con la versión oficial de las clases dominantes, sino también con la información sobre la "historia de los indios" - a veces escrita por o desde el punto de vista de ellos-, como porque hay que intentar comprender a ambas partes en sus interinfluencias y conexiones, valiéndonos no meramente de los documentos que dicen informarnos de "verdad", pues no menos interesantes pueden ser para el etnohistoriador - como señala Jiménez Núñez - las fuentes que ahacen uso sistemático de la mentira, la exageración o la crítica" (Jiménez Núñez 1994: 25).

4. Más allá del debate postmoderno: la antropología "desde" la literatura, un camino de lo real" a lo "imaginario"

Este interés, más o menos reconocido, de la obra literaria para la antropología viene a plantear varias cuestiones. En primer lugar, el de la calificación de esos textos: ¿son de valor antropológico o meramente etnográfico? Y, más allá, ¿en qué medida una obra que se confiesa "de ficción" puede aportar datos sobre la realidad de una sociedad? En esta línea, Manuel de la Fuente Lombo reivindica el derecho de la antropología a reclamar para sí - más allá de las apariencias- el estudio de "lo imaginarion:

Junto al soporte etnográfico, una antropología de lo oculto, de lo no dicho, desde el escribir imaginario, nos acerca al proyecto totalizador de nuestra disciplina, pero todo ello sin condicionantes estratégicos, sin prejuicios que desvirtúen la heterodoxia del discurso de ficción (Fuente Lombo 1997: 39-40).

Este autor reclama, en suma, para la antropología la necesidad de indagar no sólo lo que se ve, sino también lo que no se ve, lo que se 
dice y no se dice, los hechos y lo que se inventa, la realidad y la ficción: encontrar el sentido, por encima de las conductas "aparentes", la palabra o las palabras en su uso no ordinario, es decir, literario. Se trataría, pues, de no desdeñar tampoco el imaginario que existe detrás de las acciones y las palabras. Incluso de las acciones más extrañas y de las palabras aparentemente más sin sentido. Porque "el decir de la literatura no es el decir de la experiencia empírica, no es el decir de la etnografía, pero no deja de constituir una experiencia, la experiencia de la no apariencia" (Fuente Lombo 1997: 39).

En este contexto, resultaba, por supuesto, pertinente (e incluso inevitable) traer a colación - y Manuel de la Fuente Lombo así lo manifiesta- la discusión que desde la antropología llamada postmoderna se hizo sobre el carácter literario de toda escritura etnográfica, pero también sobre la distinción entre literatura y antropología. Una distinción que, a veces, ha quedado reducida a la posición del etnógrafo/a como testigo directo o no de lo contado. Recuérdese, en este sentido, la polémica levantada en torno a la obra de Florinda Donner, Shabono (1982), por tratarse de una "ficción" construida sobre obras de otros, y el esclarecedor trabajo de Mary Louisse Pratt - publicado en el ya clásico texto de la antropología postmoderna Writing Culture - respecto a este asunto. Dice Pratt:

Creo que el caso de Shabono ilustra muy claramente la confusión y ambigüedad que la narrativa en primera persona [...] esparce en el espacio discursivo de la etnografía. Obras de tono tan personal como el libro de Donner resultan cosa totalmente desconocida para la antropología academicista. En verdad, la narración, el recuento de las experiencias personales vividas en el trabajo de campo, no es sino un subgénero de la antropología. No se le otorga otra condición. De todas formas, el libro de Donner no se acompaña del imprescindible bagaje etnográfico que lo haría verosimil... Acaso sea un libro por escribir (Pratt 1991: 66).

En el Prólogo a la edición española de Writing Culture ya me referí a ese juego — del que parece arriesgado romper las reglas- entre literatura y etnografía, subjetividad y objetividad, en los siguientes términos:

¿Tiene sentido esa tácita oposición entre antropología y literatura que movía al etnógrafo a practicar un estilo romo y más que nada expositivo para no resultar "Sospechosamente" literario? ¿No convendría, por el contrario, aceptar la difícil adecuación de la expresión convencional a una experiencia tan difícil de transmitir como la del etnógrafo y buscar un lenguaje cuyas claves, al decir de Geertz, los poetas y matemáticos conocen hace tiempo? [...] Así vista, la etnografía se aproxima a una verdadera poética de la persuasión mediante la cual se nos hace partícipes de dos convicciones básicas: que el etnógrafo "estuvo allî" y que su visión interpretativa de las otras culturas es la que nosotros mismos hubiésemos suscrito de encontrarnos en su situación (Díaz G. Viana 1991:14). 
Con mayor o menor consciencia, lo que allí ya proponíamos era algo más que un cambio en los aspectos formales de la escritura etnográfica, como perfectamente entendió Manuel de la Fuente Lombo:

No se trata, por tanto, de ver al antropólogo como autor (lo que se ha venido en llamar etnografía literaria), ni de hacer una antropología de la literatura, como reprocha Díaz Viana, sino una antropología desde la literatura, para rehacer su identidad (Fuente Lombo 1994: 70).

La antropología, según ya algunos proponíamos y Manuel de la Fuente Lombo formuló con nitidez, debería replantearse —en este sentidosus propósitos y métodos más allá del trabajo de campo (y de la orientación que ha llegado casi a sacralizar esta práctica etnográfica), entendiendo - e incorporando a su quehacer- la etnoliteratura como un método que mira a la literatura culta, de autores contemporáneos o del pasado, en cuanto a fuente privilegiada y fiable para sus pesquisas. Pues como dice también este autor:

No se puede confundir lo que es sólo una estrategia escrituaria basada en la recepción estética del trabajo etnográfico, con un metodología portadora de nuevos paradigmas (Fuente Lombo 1997: 21).

Alude Manuel de la Fuente Lombo, en la misma línea, a los reproches que -en más de una ocasión- se han hecho sobre la obra de antropólogos como Caro Baroja, aquí, o Lévi-Strauss, en el ámbito internacional, por haberse dedicado escasamente — según sus detractores — al "trabajo de campon y dedicar su esfuerzo principal al manejo de fuentes -etnográficas o no- que ya existían con anterioridad (Fuente Lombo 1997: 16). Y también a otras obras de arte. Ha escrito Lévi-Strauss, por ejemplo, sobre la importancia del arte en el conocimiento de lo humano:

Suprimir al azar diez o veinte siglos de historia no afectará de manera sensible a nuestro conocimiento de la naturaleza humana. La única pérdida irreparable sería la de las obras de arte que esos siglos vieron nacer. Pues los hombres difieren e incluso existen sólo por sus obras. Como la estatua de madera que dio a luz un árbol sólo ellas aportan la evidencia de que, en el transcurso de los tiempos, algo ha sucedido realmente entre los hombres (Lévi-Strauss 1993: 128).

Aunque en algunos párrafos de sus textos parece asumir Manuel de la Fuente Lombo que la antropología postmoderna sólo ha constituido una reforma parcial respecto a los métodos antropológicos convencionales, al centrar sus críticas sobre la escritura etnográfica y, en definitiva, sobre la forma de reflejar el trabajo de campo, también -a partir precisamente de algunas citas que incluye del trabajo de Stephen Tyler y de mi Prólogo al libro ya citado (Fuente Lombo 1997: 18-21) — rescata la idea (no ajena 
al debate postmoderno) de la necesidad de ir algo más allá y plantearse, desde el estudio antropológico de la literatura, una reconstrucción de la identidad de la antropología.

Porque, para Fuente Lombo, el debate postmoderno habría resultado insuficiente (provocando más "el ruido que las nueces") y proseguido la vieja obsesión sobre el trabajo de campo, así como —al fin y al cabola identificación de la antropología con él: "El posmodernismo —escribiósigue insistiendo en la Etnografía como sinónimo de Antropología" (Fuente Lombo 1997: 21).

Si bien podía no faltarle cierta razón en lo que refiere a la desproporción entre las intenciones manifestadas (no sin grandilocuencia) por algunos de sus valedores y las consecuencias de su aplicación, o — dicho de otro modo- entre el "revuelo" ocasionado por la antropología postmoderna y sus resultados, habrá que matizar ahora, al cabo de algunos años, que el debate no fue tampoco estéril. Aunque, por ejemplo, apenas se haya reincorporado el factor de la reflexividad, enfatizado por algunos autores de esa tendencia, en la mayoría de las monografías antropológicas que siguen publicándose en España, su posible incidencia —aún demasiado escasa- no deja de estar ahí.

Porque, en mi opinión, el postmodernismo antropológico no se limitó a replantear las formas de contar lo visto, no se redujo al estudio de la "retórica de persuasión" que el antropólogo utiliza para convencer al lector de que "estuvo allíp. Al ampliar la reflexión sobre el propio trabajo amplió la dimensión del objeto y los métodos para estudiarlo. De hecho, la antropología postmoderna se construye también —en mi opinión- sobre reflexiones que vienen del propio trabajo etnográfico, y no sólo del trabajo de campo, con ser esta experiencia importante, sino igualmente del proceso de escritura. Del debate antropológico postmoderno deviene la percepción cada vez más nítida de que precisamente literatura y antropología sí tienen algo muy importante en común: la cualidad de evocación, de compartir las claves de un arte fundamentalmente "evocativon. Se cuenta lo que se ha experimentado, pues aunque en el caso de la ficción literaria se hable de algo inventado, se utilizan - también - retazos de sensaciones, fragmentos de experiencia real para hacer convincente lo narrado.

\section{Una nueva y vieja (o "clásica") forma de hacer antropología}

El término etnoliteratura, que tampoco es tan nuevo, tomaría una deriva en cierto modo nueva de acuerdo con estos propósitos de ampliar mediante ella los métodos de análisis de la antropología; pero no sólo porque reivindica el empleo de ufuentes escritas como principal fuente de 
información" —en eso sí sería una rama de la etnohistoria sin más- para aplicarla al "estudio de sociedades del pasado" (Buxó 1993: 270), sino porque incorpora lo imaginario dentro de esa aproximación. Y de ahí viene el problema: ¿cómo reducir lo ficcional a datos comparables? En el fondo, el debate apunta a una discusión más profunda, no tanto a si se puede hacer antropología que no esté basada en los datos de campo propio. Está claro que sí, y así lo hicieron los padres británicos de la disciplina como Frazer, quien se basó precisamente - a menudo- en fuentes que pueden ser consideradas fundamentalmente como literarias. Sigmund Freud, al tiempo que hacía notar las dificultades que presentaba esa forma de obrar de los primeros grandes antropólogos (Freud 1968: 217), eligió él mismo un método que combinaba - junto la experiencia clínica- las fuentes etnográficas aportadas por autores como Frazer o Robertson Smith, junto a otras que no eran si no las obras clásicas de la Humanidad. Un ejemplo claro de esta práctica lo constituye Totem y tabú de Freud (1913), en que éste reivindica el análisis de los mitos de la antigüedad clásica con un fin científico.

Porque la propuesta expuesta por Fuente Lombo y Jiménez Núñez puede y debe ser revisada en un aspecto que, al darse por sentado, deja otros no menos importantes sujetos a interpretación futura. Me refiero a que, en su reivindicación de las fuentes netamente literarias - las obras escritas, de ficción y pertenecientes a la literatura considerada como culta-, nada (o poco) se dice de las manifestaciones literarias que no lo son. Textos o no-textos, según la definición de Lord (1960) que han quedado fuera de la historia de la gran literatura y que, sin embargo, como espero mostrar aquí, resultan de gran importancia - y en varios sentidospara la labor del antropólogo. Me estoy refiriendo a la literatura considerada como oral y folklórica, o a las propias historias de vida -esa otra forma de biografía - que a menudo recopilan los antropólogos y que no sólo incluyen cuentos o leyendas en sus ficciones, sino que pueden ser vistas ellas mismas como una ficción literaria en muchos aspectos. Sin olvidar que la antropología, precisamente por esa mitificación o sobrevaloración del trabajo de campo que revisan Fuente Lombo y Jiménez Núñez, ha incorporado - desde sus comienzos- como parte sustancial de su quehacer testimonios orales, también susceptibles de entenderse como literatura.

La etnografía se hace en gran medida sobre lo dicho (mediante encuestas, entrevistas, relatos) y, aunque la competencia lingüística de los antropólogos en la lengua de la cultura que pretendían estudiar ha sido no pocas veces puesta en entredicho por la rapidez con que el etnógrafo aseguraba haberla aprendido (Barley 1983), lo cierto es que -autocríticas 
aparte- el antropólogo trabaja sobre discursos orales que transcribe para hacerlos lenguaje escrito. A menudo, los antropólogos se han valido de informantes que -a su vez- les hacían de traductores, lo que complica el proceso de traducción de una cultura a otra, pues el mediador nativo puede haber reconstruido previamente, en no pocas ocasiones, su identidad exótica para hacerla más atractiva al investigador.

En todo caso, se puede decir que la antropología se entrecruza con el lenguaje $-\mathrm{y}$ lo literario- en un doble sentido: porque arranca o parte -principalmente- del proceso comunicativo (si bien cabe en ella la observación de comportamientos no verbales y la utilización de otra clase de fuentes) y se cierra con la redacción de un texto, es decir, con la escritura etnográfica que plasma tanto la experiencia del etnógrafo como la de sus estudiados, sus palabras como las de "los otros".

Aceptada esta realidad, no siempre suficientemente contemplada por los historiadores y tratadistas de la disciplina, podrá comprenderse lo que queremos expresar cuando preferimos hablar de la etnoliteratura como de un modo de entender la antropología, de una identidad de la antropología construida - a través de ella- "desde" la literatura y no de la etnoliteratura como una mera etnología o antropología de la literatura, de la etnoliteratura como simple antropología literaria o rama del oficio antropológico. De hecho, lo que estamos proponiendo - en la misma línea que Fuente Lombo ya sugiriera - es concebir a la etnoliteratura como un método más que como un campo, una cuestión de modo de trabajar más que de contenidos. No obstante, puede objetarse que hay aspectos de la antropología que sí caben dentro del marco o enfoque de lo etnoliterario y otros que no. Por lo que sería conveniente, antes de continuar, el precisar qué materias son las que especialmente conciernen a la etnoliteratura como antropología o manera de entender lo antropológico.

\section{ANTROPOLOGÍA LITERARIA Y ARTE VERBAL}

\section{Literatura, folklore $y$ arte verbal}

Ha señalado, de otro lado, Caramés Lage en un trabajo en que pasa revista a los inicios y autores de esta línea de trabajo en España, como es el caso de Fuente Lombo y el que esto escribe:

La Antropología Literaria trata de aproximarse al texto escrito desde un punto de vista antropológico; de aquí que el crítico literario se vea a sí mismo como un etnógrafo dentro de una nueva hermenéutica (Caramés Lage 2004: 2).

Vemos que, si bien se utiliza aquí el término de antropología literaria y no etnoliteratura, el sentido de la proposición es el mismo, hacer una 
antropología no sólo "de la literatura", sino también "desde" la literatura. Otra cosa es que se consiga. Pero ¿qué entenderíamos por literatura en tal contexto? Probablemente muchos estarían de acuerdo con las definiciones más convencionales de literatura, según las cuales ésta sería la expresión del arte por medio de la palabra o crear belleza con las palabras. Una concepción que remitiría tanto a lo oral como a lo escrito siempre que la palabra sea utilizada con "arte». Pues la literatura sería el arte de nombrar lo inefable, lo que "normalmente" no puede ser dicho o expresado.

Dentro del conjunto de manifestaciones que vienen considerándose como folklore - desde la aparición de este término- hay una serie de ellas que están estrechamente relacionadas con la palabra, con el uso literario o artístico de la misma, y a las que, por ello, se ha denominado -también- con perífrasis diversas que siempre hacían referencia a la literatura. Esto es especialmente apreciable en la tradición anglosajona de estudios folklóricos donde ese grupo de expresiones literarias tendieron a ser consideradas, en cierto modo, el corazón del folklore, o su más genuino objeto de interés, llegando el mismo a ser —en no pocas ocasiones- identificado con aquéllas.

Fue el antropólogo William Bascom quien ya señaló cómo los términos unwritten literature, popular literature, folk literature, primitive literature, y oral literature enfatizaban la relación de todas estas formas con la "literatura" (Bascom 1981: 67). Y acuñó un término tampoco tan nuevo, el de "arte verbal", para definir lo que en realidad era el objeto hacia el que apuntaban todas las denominaciones utilizadas. Este término tiene una ventaja para el asunto que nos interesa. Hace alusión a un arte expresado mediante la palabra que se supone oral, pero podría servir también para referirse a la palabra escrita. Y, de hecho, el estudio de la literatura comprendida dentro del campo del folklore ha puesto de manifiesto que lo oral y escrito no son mundos irreconciliables, que - muy al contrario- son estadios por los que, con frecuencia, atraviesa una misma creación. Incluso, las manifestaciones folklóricas son fijadas por escrito y a menudo devueltas al cauce de lo oral (Burke 1981).

La llamada Literatura de Cordel, que recibe diversos nombres según las tradiciones, demuestra esta interinfluencia (Díaz G. Viana 2000). La etnoliteratura, desde tal perspectiva, podría redefinirse como la parte $\mathrm{O}$ aspecto de la antropología que estudia todo arte verbal. Y sería un término que sirve para aludir no sólo a las creaciones literarias del folklore, sino también para referirse a la literatura en general, sobre todo cuando esa línea de investigación de estudios folklóricos ha aportado y mostrado el camino a enfoques que relacionan ambas tradiciones, las tenidas como culta y popular. 
El propio Bascom señalaba que la denominación de "arte verbal" evita, por un lado, la inconsistencia de referirse a la literatura oral, popular o - - definitiva - no culta ni convencional como "literatura no escrita": lo que, sin duda $-\mathrm{y}$ como señala este autor-, constituye un contrasentido etimológico, pues diteratura es etimológicamente aquello que se escribe" (Bascom 1981: 67). También, de otra parte, evita la utilización de la expresión "arte verbal" algunas dificultades apuntadas por Bascom, como que el término de folklore -y la literatura folklórica dentro de él-, por englobar todas las expresiones estéticas en clave popular, llegue a resul$\operatorname{tar} \tan$ confuso en su definición como cuestionable en cuanto a disciplina científica. El folklore sólo artificiosamente es separable de la cultura en su totalidad y de la manera de transmitirse ésta, que no es otra que la del consenso y la tradición. Pues tan "tradicional" o mediante "tradición" se comunica y perpetúa la "cultura popular" como la "cultura de los cultos", también llamada "hegemónica", "alta" o "Gran cultura". Dice Bascom:

El arte verbal difiere del habla ordinaria de la misma manera que la música lo hace del ruido, que la danza difiere de andar o que una banqueta africana difiere de un bloque de madera (Bascom 1981: 69).

Pero el mismo Bascom reconoce que, en esencia, lo "verbal" puede referirse tanto a palabras escritas o habladas, aunque comúnmente se tienda a identificar "verbal" con palabras habladas y "de ahí que se identifique con lo dicho, con lo hablado" (Bascom 1981: 67).

Sobre el concepto de arte -que sería aún más discutible - comenta Bascom que podemos estar de acuerdo en considerarlo "la elaboración más allá del punto de utilidad", si bien él propone la mínima definición de arte como aquello que concierne "a las formas creadas para el propio gusto o placer" (Bascom 1981: 68).

El arte verbal para Bascom es "intangible y dinámico", a diferencia de las artes gráficas y plásticas que precisan un soporte material para sustentarse (Bascom 1981: 70). Mas quiero apuntar, aquí, por su interés para la redefinición de etnoliteratura en su sentido epistemológico, que los trasvases de lo oral a lo escrito son frecuentes tanto en la vertiente de la Gran tradición como de la Pequeña (Redfield 1960); que muchos escritores fueron y han seguido siendo - pues lo son a través de su escrituranarradores en cierto modo orales; que el arte verbal a menudo queda fijado por escrito, por amanuenses o recopiladores; y que esa actividad se retroalimenta con la transmisión oral.

Por todo ello, quiero rescatar también el concepto de Bascom de arte verbal para redefinir a la etnoliteratura $-\mathrm{y}$ acotar el objeto de estudio de ésta- como la antropología del arte verbal que englobaría lo oral y lo 
escrito, lo culto y lo folklórico. Arte como la búsqueda del placer, literatura como la búsqueda de ese placer en el lenguaje y antropología —en cuanto a etnoliteratura - como la indagación de lo humano en esa "búsqueda del placer mediante la palabran (Bascom 1981: 75).

\section{Lenguaje, comunicación y arte de la palabra}

Ya Vladimir Propp señaló que el folklore como la literatura es un arte verbal" y, tal cómo él —con otros muchos folkloristas- lo entendía, un fenómeno literario que se solapa con la literatura convencional en sus géneros poéticos (Propp 1984: 6). Y añadía que es una forma especial de arte verbal porque posee una poética distintiva (Propp 1984:5). De las diferencias entre folklore y literatura, Propp destaca una bien conocida y recurrentemente mencionada: que la literatura tiene autor conocido y el folklore no, lo que no siempre resulta tan claro. Quizá más significativo es que la obra literaria está - por lo general- formalmente terminada y que el folklore se recrea constantemente e incluso que vive o se transforma más allá de los grupos o individuos que inicialmente lo crearon.

En este sentido, llega a afirmar Propp que, en su origen, ael folklore está ligado no a la literatura sino al lenguajen, que nace en cualquier lugar y cambia de una manera regular, e independientemente de la gente (Propp 1984: 7). Acertadamente, Propp apuntó que la distinción de que el folklore es transmitido oralmente y la literatura mediante la escritura no es tan importante como la diferencia que este hecho marca entre el funcionamiento de literatura y folklore. Una obra literaria no cambiaría a lo largo del tiempo y el folklore sí. La obra de folklore existe en constante flujo porque "el folklore circula cambiando todo el tiempo y esta circulación y dinamismo están entre sus características específicas" (Propp 1984: 8).

Habla Propp, en la misma línea, de que una obra literaria "vuelta" en folklore no es diferente de una obra de teatro representada con ninguna o leves transformaciones del texto, si sólo se transmite fielmente. Si la obra cambia es cuando se convierte en folklore. Pero la cosa no siempre resulta tan simple. Él habla, así, de que puede haber una obra literaria en origen, pero que se convierte en folklore por el modo de transmisión (Propp 1984: 9).

Acepta Propp que esos casos dudosos son muy frecuentes y que "los lazos entre literatura y folklore, así como las fuentes literarias del folklore están entre los más interesantes temas de estudio para ambos, en la historia de la literatura y del folklore" (Propp 1984: 9). Hay muchos grados intermedios -como Propp explica- entre un hipotético primer caso, el de un afolklore no creado por un individuo concreto en tiempos prehis- 
tóricos dentro del marco de un ritual o en cualquier otra manera y que ha sobrevivido a través de la transmisión oral hasta el presenten; y el segundo caso, que sería "el de una obra individual reciente circulando después como folklore" (Propp 1984: 9).

Quiero defender, tras lo ya expuesto, la propuesta de que toda literatura es arte verbal, pues remite a la palabra y al sonido, a su efecto estético; y que folklore y literatura $\longrightarrow$ mejor, que la literatura entendida como culta y la literatura folklórica- se diferencian, fundamentalmente, en sus formas de transmisión y en las características que su proceso de creación confieren a cada una. Lo que - sin duda- no es poco, pero no del todo sustancial.

\section{Folklore y antropología}

De otro lado, las diferencias entre folklore y antropología son también un poco engañosas. Como el propio Propp señala, parecería que la distinción estriba en que, si un etnógrafo recoge relatos orales de otra cultura, eso puede considerarse etnografía, etnología o antropología, y si lo hace en la propia eso será folklore. Dice Propp sensatamente sobre ello:

La ciencia del folklore atañe al arte de todos los pueblos, independientemente de quienes lo estudian. Folklore así es un "fenómeno internacional" [transnacional o universal podríamos — también- decir] (Propp 1984: 5).

También descarta Propp la aproximación que entiende el folklore como propio de las clases desfavorecidas en las sociedades desarrolladas:

Una pregunta natural surge: ¿qué es folklore en una sociedad sin clase, bajo el socialismo? Podría parecer que el folklore, como fenómeno de clase, desaparecería. Sin embargo, la literatura es también un fenómeno de clase pero no desaparece (Propp 1984: 5).

Folklore, viene a decir por lo tanto Propp, pueden ser cosas diferentes bajo el socialismo y el capitalismo, pero —en todo caso- el folklore sigue existiendo. ¿Por qué? Folklore y literatura tienen que ver con la capacidad de todo hombre de contar y contarse. Además, no está nada claro -como ya sabemos por la experiencia habida en los países gobernados por el comunismo- que las clases y el pueblo desaparezcan en una sociedad socialista.

Remiten literatura y folklore a la capacidad de los seres humanos de comunicarse y representarse en palabras. Y, más aún, de ser humanos - precisamente- porque podemos contarnos a través de lo que somos y de lo que no somos, e incluso de lo que podríamos ser. La antropología 
no puede eludir todas las posibilidades y dimensiones que caracterizan lo humano. Lo que se ve y lo que creemos ver. Lo que se piensa y lo que se imagina.

Ya escribí, en otro lugar, que - a menudo- la etnografía parece empantanarse en dicotomías artificiosas como la de antropología/folklore; o en debates en falso, como posiblemente fue, en cierto sentido, el de la antropología llamada postmoderna:

\begin{abstract}
Hay una serie de problemas que la antropología siempre ha arrastrado como actividad y discurso y que esta revisión - sólo aparentemente novedosa- nos revela de la manera más rotunda. Problemas que, ahora, habremos de abordar con mayor consciencia, pues no pocos debates del pasado estuvieron - ya- relacionados con las diversas maneras de intentar darles una solución. Y es que todo etnógrafo que no se limite a coleccionar y etiquetar datos debería - y debeenfrentarse con las "fisuras", "quiebras" o rupturas entre los principales conceptos y términos con que trabaja: oralidad y textualidad; subjetividad y objetividad; experiencia y comportamientos; civilización y salvajismo; lo universal y lo particular; lo extraño y lo propio; lo urbano y lo rural; su cultura y las otras culturas; la observación y la participación; la relación del antropólogo y sus informantes; teoría y método; trabajo de campo y escritura. Distinguir y conjugar con sutileza y rigor todos estos elementos es nuestra tarea. Nosotros somos nuestro propio instrumento y principal herramienta de investigación. Lo humano como método y como objetivo. El discurso de lo extraño desde el conocimiento de lo propio (Díaz G. Viana 1997: 216).
\end{abstract}

\title{
4. La antropología "desde" la literatura o la decodificación de las expresiones de lo verbal
}

Manuel de la Fuente Lombo abogaba por la elección de la etnoliteratura como "método antropológico" que devolviera a la antropología su papel primigenio en cuanto a disciplina con vocación científica de preocuparse por "todo" lo humano. Y se preguntaba: "Por qué ese olvido y distanciamiento de la teoría antropológica de nuevas claves explicativas de la condición humana?" (Fuente Lombo 1994: 53). La respuesta sería que, en su opinión "ha habido - y hay- una dejación de la teoría antropológica", pues "se ha hecho mucha etnografía y menos antropología" (Fuente Lombo 1994: 55).

Sin embargo, quizá podamos no estar del todo de acuerdo con esta aseveración si miramos hacia la etnografía española de los últimos años, en la que los trabajos estrictamente etnográficos no abundan tanto como cabría suponer, pero - en el fondo- estaríamos dispuestos a aceptar que, como él señala, la antropología (aquí y en muchos otros lugares) se ha fallado a sí misma en su indagación sobre lo humano. $\mathrm{Y}$ es que, como 
ha escrito también Llobera, los antropólogos pueden haber privilegiado en exceso determinados aspectos de su labor descuidando otros:

la antropología ha endiosado el nivel inicial de la investigación científica, es decir, la recogida de datos, la descripción de una comunidad, y lo ha convertido en el deus ex maquina de la disciplina (Llobera 1990: 32).

Lo cierto es que muchos de los trabajos antropológicos que en la actualidad se publican - $-\mathrm{y}$ no sólo por parte de antropólogos españoles- más que meramente etnográficos son una mezcla de teorías en boga con un poco de etnografía, dicho de otra manera: una olla con una pizca de esto y de lo otro y de lo de más allá. Llobera, de otro lado, parece responsabilizar en parte al debate postmoderno de ese endiosamiento, cuando en realidad la entronización de la etnografía como "estado de gracia" y única antropología científica es bastante anterior, según ya hemos visto (Llobera 1990: 56).

Pensaba Fuente Lombo, por el contrario, que de esos debates surgía cierta luz y que la antropología podría, a partir de ahí, recuperar su camino. Creía este autor que la antropología superaría mejor sus laberintos interdisciplinares si se reencauzaba dentro de la etnoliteratura, pues ésta tenía la ventaja de no estar $\longrightarrow$ estar en menor medida - condicionada por la temporalidad, fuera para afirmarla o negarla:

Pues puede instrumentarse en un texto grecolatino, en una novela de Cervantes o en una pieza dramática de Samuel Becket (Fuente Lombo 1994: 58).

Ni más ni menos que como ya habían hecho los "padres" británicos de la disciplina mostrando el camino en el siglo XIX. Y recurría Manuel de la Fuente Lombo a unas palabras de Fernando Savater $-\mathrm{y}$ otras voces de fuera de la disciplina- para describir el verdadero estado de los estudios antropológicos y su atolladero:

Uno de los mayores fraudes intelectuales de nuestro siglo es haber llamado antropología lo que suele ser habitualmente etnografía y todo lo más etnología. De este modo, la reflexión conceptual sobre lo común a la condición humana se ve sustituida por descripciones y observaciones de particularidades (a menudo fascinantes) que, en vez de servir como punto de partida al pensamiento, se presentan como su logro final (Savater 1992: 16).

Manuel de la Fuente Lombo estaba, a mi parecer, en lo correcto al reflexionar sobre lo humano desde lo literario. Pues quizá sólo empieza a existir la humanidad como tal cuando es capaz el hombre de contarse a sí mismo, de reconocerse distinto de lo otro. Probablemente desde que dibujó un animal sabiendo que era otro ser diferente, un ser que él podía describir y apropiarse, antes incluso de representarse a sí mismo. Desde 
que puso nombre - e hizo suyos - a esos otros seres que empezaba a representar con la imagen o la palabra. Dice al respecto:

No se me escapan las dificultades y obstáculos, inherentes a la puesta de largo de la etnoliteratura como método antropológico [...] esta Antropología desde la Literatura no implica de ninguna manera que nos convirtamos en escritores ni que los escritores se transformen en antropólogos; es un encuentro sin prestaciones mutuas, sin dejación de nuestra identidad: muy al contrario, el estudio de la condición humana desde esta perspectiva - la experiencia de la no aparienciapuede favorecer el rehacimiento de esa identidad. A ello vamos (Fuente Lombo 1994: 59).

Ambicioso, pero no descabellado propósito. Poeta y antropólogo coinciden porque "los dos bucean para alcanzar el significado último sumergido debajo de la cáscara de las cosas" (Lisón Tolosana 1983: 136). Y dice Manuel de la Fuente Lombo a propósito de ello:

Pues bien, la pertinencia de la Etnoliteratura como método antropológico, se explicita en esa tarea de alcanzar la realidad sumergida (Fuente Lombo 1994: 62).

El antropólogo revela $\longrightarrow$ habría de revelar - las profundidades de lo humano, lo que no se ve pero hace que lo humano transforme el mundo a través de nuestra mirada previa. Antes de pintar a los animales el hombre que los pintó los descubre, los ve en los salientes de la piedra. Luego, mediante la acción de su mano o su palabra, se apropiará intelectualmente de ellos. La convención del símbolo y el nombre hace posible el reconocimiento colectivo de lo que allí está representado. $Y$ todavía nosotros, hoy, podemos también reconocerlo (aunque nos falten detalles que ignoramos), demostrándose así que no éramos - no podíamos ser- tan diferentes.

\section{Tareas de la antropología: la condición bumana como problema}

No se trataría, pues, sólo de describir lo que los hombres hacen sino de indagar sobre por qué se hacen las cosas de una determinada manera; una diferente manera según las culturas pero siempre la misma cosa. Porque, a menudo, se ha descrito la diferencia entre culturas - como señala Fuente Lombo- de modo que parezca que "lo característico de los humanos es que están haciendo cosas permanentemente" y "la etnografía se convierta, así, más en una mirada a lo que la gente hace [...] y menos en un estudio de lo que a la gente le pasa" (Fuente Lombo 1997: 12). Hay, no obstante, quienes pretenden hablar de lo que otros grupos - los observados- sienten, pero quizá tengan razón quienes consideran que el etnógrafo puede describir comportamientos pero no tanto sensaciones 
de otros (Turner y Bruner 1986). Él —posiblemente- no sentirá lo que otros sienten aunque esté en la misma situación. Pero sí puede tratar de lo que otros imaginan, es decir, de las imágenes a través de las cuales todos preconceptualizamos las cosas. ¿Cómo? Analizando, por ejemplo, las historias con las que la gente se explica el mundo.

No podemos saber cómo nombraban las cosas los hombres de Altamira, pero sí cómo veían el mundo. Tenemos las imágenes, aunque nos falte el texto. O quizá no, ya que parte de él —como he apuntado al principio- se habrá continuado, posiblemente, en mitos posteriores que sí conocemos. Pero lo que no sabemos es lo que estos mitos deben a épocas prehistóricas y lo que se ha actualizado en cada época. No importa: existe en los mitos una continuidad que, además, los hace semejantes $\mathrm{y}$, a veces, sorprendentemente similares a través de las distintas culturas. Dice Manuel de la Fuente Lombo:

Tengo la sospecha de que el trabajo de campo ha sido, en parte, y sigue siendo, no sólo la marca fronteriza que ha decidido la cualificación profesional y hasta la nominación como antropólogos, sino las alas de avestruz que, a modo de escudo protector, han librado a la clase antropológica del compromiso de tener que enfrentarse a esas otras experiencias que se esconden en la trastienda de la condición humana (Fuente Lombo 1994: 62).

Pasemos a esa trastienda. Adentrémonos en lo menos visible. Cómo se ve la realidad, cómo la imaginamos, acaba influyendo en la conformación de lo visto tanto o más que lo que esa realidad pueda influir en nosotros. El Nuevo Mundo, por ejemplo, lo hicieron hombres que fueron a América con una mentalidad caballeresca y el romancero en los labios. Ese pre-mundo de los primeros "conquistadores" $\multimap$ los modelos bíblicos y de la Antigüedad clásica que los cronistas, más tarde, utilizaron repetidamente para acercar lo que veían a lo que ya era conocido- contribuyó a describir lo que descubrían, de tal manera que marcó una impronta imborrable en cómo ahora lo seguimos viendo: en cómo llegó a hacerse y en cómo lo conocemos. Ha escrito Fermín del Pino a propósito de ello:

El presentismo temido por Stocking sólo se presentaría en nuestra proximidad antropológica con las Crónicas de Indias —en nuestra edición modernizada-, si fuésemos insensibles al lenguaje y la cultura de sus autores, si quisiéramos convertirlos en "antropólogos" —o usarlos como cantera de datos- a nuestra conveniencia [...] Pero, si la proximidad que sentimos con ellos es natural, si no tenemos que forzar nada - ni en ellos ni en nosotros- entonces creo que habremos logrado una "cercanía cultural" con lo lejano (Pino Díaz 1997: 194).

Dice, también, el zorro de El principito - y así lo cita Fuente Lombo-.

He aquí mi secreto. Es muy sencillo. Consiste en que no se ve bien sino con el corazón, pues lo esencial es invisible a los ojos (Saint-Exupéry 1979: 76). 
Literatura y antropología no tienen por qué confundirse, sino todo lo contrario. Pero ésta no puede prescindir de lo literario o arte verbal ni como objeto de estudio, ni como método de análisis, ni como forma de expresarse o darse a conocer. Esto va más allá de la obviedad con que -según recordábamos al comienzo- Geertz describía el quehacer del antropólogo: los antropólogos escriben. Además, los antropólogos necesitamos de lo literario en todos los estadios de nuestra labor. Para que nos cuenten, para ver qué nos cuentan y para contar y contarnos de la manera más precisa y eficaz.

La experiencia de la no apariencia es para la literatura su razón de ser, para la Etnoliteratura como método antropológico es una razón para conocer, para entender el mundo y el hombre (Fuente Lombo 1994: 69).

La cuestión no es, pues, diferenciar literatura y antropología, marcar la distinción entre lo que es verdad o mentira, sino en la importancia que incluso las "mentiras" - los mitos- pueden tener en la reordenación del mundo. La etnoliteratura que reivindicamos radica en la búsqueda de una antropología desde la literatura, más que en la autosatisfacción ante la etnografía literaria de cierta antropología postmoderna o en una vacua antropología de la literatura "apenas sustentada en cualquiera de las dos ramas" (Díaz G. Viana 1991: 19).

Tenía razón Manuel de la Fuente Lombo en sospechar "que en el discurso de la Antropología Social/Cultural, se ha trabajado más en la adjetivación (Social/Cultural), y menos en la sustantivación: Antropología. En definitiva, el problema sería que la Antropología llegara a ser lo que casi nunca ha sido en la modernidad/postmodernidad: el estudio de la condición humana como problema" (Fuente Lombo 1994: 70).

Para contestar a la pregunta de cuándo empieza a existir el hombre -que se hacen los paleoantropólogos- hay que contestar antes qué es o qué vamos a considerar que es lo humano. No podemos decir cuándo empieza y de ahí decidir qué es: el proceso debe consistir justamente en lo contrario para evitar una estéril circularidad, el circunloquio y la vana tautología. Y sólo la antropología sin prefijos ni adjetivos puede -de verdad- servirnos para definir qué es lo humano y para construir el proyecto de lo que queremos que sea. Si es que pretendemos que el hombre pueda "dominar - y ser dueño de- su destino", como proponía Gramsci. Lo que — sin duda- constituye la más "humana" de nuestras expectativas. 


\section{A MODO DE CONCLUSIÓN: ENCRUCIJADA DE LA ANTROPOLOGÍA EN LA ACTUALIDAD}

Las disciplinas científicas se definen habitualmente por su objeto, metodología e historia: resumiendo lo dicho, creo que podemos concluir que la etnoliteratura como manera de hacer antropología o, más exactamente - según proponía Manuel de la Fuente Lombo-, como camino para rehacer su identidad se caracteriza por los siguientes aspectos. En cuanto a objeto, por la decodificación e indagación de todas las expresiones que remiten a ese arte verbal al que ya nos hemos referido o - dicho de otro modo- al uso creativo de la palabra (ya sea escrita u oral). En cuanto a su metodología, por el análisis de lo literario desde un punto de vista antropológico, es decir, por lo que podemos averiguar sobre lo humano en la literatura, pues no se trataría sólo de hacer etnografía de la literatura, sino de descubrir cómo la literatura define y conforma la percepción de la realidad que tienen los hombres, cómo nos ayuda a conocer lo no evidente en ellos, su cosmovisión e imaginario. En cuanto a la historia, por lo que la etnoliteratura tiene de regreso y recuperación de la identidad que la antropología parece haber ido perdiendo u olvidando, ya que su principal propósito era $-\mathrm{y}$, en mi opinión, es- la definición y comprensión de la universalidad de lo humano en las diferentes culturas, dado que las culturas no importarían tanto per se, como asunto aparte, sino en cuanto a variaciones de ese conjunto o plan general; en este sentido folklore y antropología no difieren tanto como, a veces, las maneras de contar sus respectivas historias pretenden hacerlo, dado que ambas recurren - principalmente- a la utilización imaginativa de la palabra.

Por último, ¿qué aporta esta revisión o reconstrucción de la identidad antropológica a la práctica de esta disciplina en el momento actual? Podría responderse que un enfoque más amplio, sin duda, pero también -aunque ello suene a paradójico- uno más concreto, más preciso. Y ello, probablemente, puede resultar muy necesario en esta época de grandes transformaciones que ya se ha calificado como "era de la globalización". Una pregunta que muchos profesionales de la antropología vienen haciéndose, de distintas formas, en tiempos recientes, es si los cambios acaecidos en el mundo como consecuencia de la globalización deberían verse reflejados en los enfoques que la antropología ha venido empleando para estudiar la cultura. Si ésta, en suma, no habría de "actualizar" sus planteamientos teóricos y metodológicos a tenor de la nueva situación.

La respuesta es sí y no, a partes iguales. Puede que la realidad haya corrido más que nosotros, pero sólo en la medida en que permaneciéramos anclados en algunos enfoques del inmediato pasado que posterga- 
ron los verdaderos intereses de la disciplina. Vienen muchos antropólogos, así, de una etapa anterior en que lo predominante fue el estudio de las "comunidades campesinas" en trance de desaparición. Como antes otros vinieron de una época en que la investigación se centraba en estudiar la cultura de los "primitivos contemporáneos" que aún quedaban. No pocos siguen asidos a las excelencias de su "pueblo" o "cultura" como si éstos fueran los más singulares o interesantes del mundo. La secuencia tiene cierta lógica interna: como el folklorista pensaba hacer $-\mathrm{y}$ algunos aún creen seguir haciendo-, ese tipo de antropólogos rescataban modelos de vida en peligro de desaparecer. Es así como la realidad se adelantó a nosotros y a nuestros propósitos.

En realidad, estudiar a los "primitivos" o a los "campesinos", o -más tarde- a los grupos exóticos y marginales de la propia ciudad (dentro de la llamada antropología urbana, uno de los últimos virajes que dio la antropología en su búsqueda de "grupos observables") contribuyó a hacer creer que tal era el fin u objetivo de la antropología, cuando - como mucho- era nada más uno de los posibles medios de realizar el trabajo antropológico. Ciertos tipos de vida "primitiva" o "campesina" desaparecieron. Paralelamente, otro proceso reduccionista se iba -también- produciendo: los primeros y ambiciosos objetivos de la antropología se reducían o asimilaban a un solo método, el trabajo de campo, y éste —en algunos casos- a las meras técnicas de entrevistas, encuestas o recopilación. Pero los antropólogos más influyentes no han sido, con todo, los que estudiaban un aspecto o varios de una comunidad concreta, sino -en general- quienes se planteaban proyectos de más amplio aliento, aunque fueran señalados desde dentro de la propia disciplina por su tendencia a mezclar saberes o por hacer, solamente, "antropología de gabinete". Pues parecía que la antropología únicamente debiera ocuparse de temas cada vez más limitados en comunidades de primitivos o campesinos.

Sin embargo, la sustancia de lo humano estudiable por el antropólogo sigue estando a nuestro lado y no únicamente en cuanto a "supervivencias" o survivals. Sólo hay que saber verlo. Aprender a reconocerlo. Ése es posiblemente nuestro verdadero trabajo: reconocer las distintas formas de lo universalmente humano en las diversas culturas, comenzando por nosotros mismos. Pocos medios más adecuados para ello que el estudio de las invenciones literarias, sea cual sea su forma o medio. Pues no sólo lo oral y lo escrito sirven para vehicular, ya, el uso artístico de la palabra y, así, la llamada cultura popular se transmite y propaga - hoy-, por ejemplo, a través de Internet: rumores, leyendas, chistes o cuentecillos nacen y renacen, diversificándose en variantes, por la red de redes (Díaz G. Viana 2003: 41-46). 
Es un hecho conocido que, en los últimos tiempos, la antropología desplazó sus intereses a campos más amplios, osando incluso adentrarse en los entresijos de las sociedades conocidas como "complejas". También resulta constatable que se siguió estudiando en este nuevo ámbito temas que siempre fueron de importancia para la disciplina, como las instituciones, la estructura o el control social; y que otros nuevos asuntos globales (como el de la inmigración del tercero al primer mundo) fueron abordados - por primera vez- antropológicamente. No obstante, hasta si se trataba de zambullirse en el marco (durante mucho tiempo obviado o eludido por los antropólogos) de lo urbano, pudo parecer —en más de una ocasión - que la antropología consistía en preguntar, allí, a gente bastante "rara" cosas demasiado obvias. Es decir, que proseguiría la práctica de buscar el exotismo - ahora- "en casa", con los mismos métodos y técnicas, aunque el escenario hubiera cambiado.

El que aquí haya utilizado el término etnografía casi siempre con algún adjetivo que podría parecer negativo o peyorativo no constituye -en realidad- menosprecio del método considerado como etnográfico, sino todo lo contrario. Es un intento de no estigmatizar - precisamente- a la etnografía en su conjunto, sino de delimitar el tipo de prácticas etnográficas que han empobrecido la labor antropológica. El método que se reivindica como etnoliterario no difiere en esencia del etnográfico, puesto que pretende devolver a éste su profundidad y amplitud, su dimensión más completa: la que incorporaría la base textual, contextual y de "entextualización" de lo que no se habla pero es descrito o transmitido de algún modo.

Se retoma, pues, el planteamiento hecho por Manuel de la Fuente Lombo de considerar a la etnoliteratura una antropología hecha desde -más que de- la literatura. Y se reivindica la importancia de lo literario en los distintos procesos del trabajo antropológico: por la textualización y entextualización presentes en el trabajo de campo, por la necesidad de combinar distintas fuentes orales y escritas en el método etnográfico y por la evidencia de que las etnografías se escriben y, por lo tanto, terminan siendo obras literarias en el más amplio sentido. La etnoliteratura en este sentido habría de ocuparse de todo el arte verbal ya sea oral o escrito. Se intenta superar también la engañosa oposición entre etnografía y antropología procurando devolver a la antropología y al propio método etnográfico su dimensión profunda de abordar lo humano en su universalidad y particularidades, liberando al trabajo antropológico del empobrecimiento al que la consagración de las técnicas del trabajo de campo le ha podido conducir en muchos casos. La etnoliteratura, pues, sería - sobre todo- una forma de entender y hacer la antropología y el camino para restituir al método etnográfico su más cabal sentido. 
Actualmente, se aprecia en la disciplina antropológica una cierta dualidad entre quienes practican una etnografía pegada al terreno, aún fundamentalmente sincrónica y local, y quienes - sin eludirla por completo- siguen estando más interesados en teorizar y reflexionar sobre lo universalmente humano en el espacio y en el tiempo. Quienes no por hacer antropología dan la espalda a la filosofía, la literatura o la historia, sino que -justamente por ello- relacionan disciplinas, épocas y culturas de la forma en que nada más la antropología puede efectuarlo. Si bien la lectura de algunos textos recientes que recogen los trabajos de destacados autores - ya sean nacionales o foráneos- pueda dar la impresión de un caleidoscopio muy heterogéneo, tanto en los temas tratados como en la forma de abordarlos, también resulta factible rastrear un cierto giro en la disciplina que —quizá- constituya un verdadero cambio de tendencia.

Tal es el caso de la compilación Culturas en contacto. Encuentros y desencuentros (García y Barañano 2003) donde, tras esa variedad o aparente atomización caleidoscópica que - desde el punto de vista más negativo- podría interpretarse como una amenaza a la identidad de la antropología, otro mensaje se abre paso: el mensaje no explícito aún que parece apuntar a si la antropología no debería liberarse de tanta etnografía candorosa sobre las "singularidades" y replantearse, con todo rigor, su ubicación respecto al poder y su papel ante los rápidos cambios que se están produciendo. Si no ha de pasar de mero testigo del desasosiego o notario de las pérdidas a desempeñar una función más activa y —quizá- más combativa. Pues no debemos tampoco, ya, limitarnos a ser -impunemente- meros observadores de los hechos. Menos - todavíade las realidades a punto de extinguirse. Lo que debemos preguntarnos es por qué esas realidades desaparecen o tienen que desaparecer. Pues los argumentos que sirven para denunciar los abusos contra la autonomía de las comunidades indígenas pueden $-\mathrm{y}$ deben - servir para desenmascarar el abandono o museificación de las comunidades rurales en nuestro mismo entorno. Es decir, que tanto habría que combatir el discurso de la inevitabilidad de la desaparición de los "primitivos" como la desertización o degradación del campo más próximo a nuestro entorno.

En cierto modo, parece que el discurso que se pretende meramente etnográfico empieza a hacer agua. El espejo devuelve, con frecuencia, un monstruo para exhibir en las ferias. Y el papel del antropólogo no puede seguir siendo el de lamentarse de que algo valioso desaparece, sino preguntarse por qué tiene que desaparecer y con qué será reemplazado. La globalización ha puesto al antropólogo en el borde de su capacidad de reflexión, al límite de sus pasadas e inmediatas contradicciones. Y, por 
eso, la antropología debe reclamar para sí su insustituible oficio de pensar - y reflexionar - sobre lo humano con la mayor libertad.

Porque, en estos momentos de globalización e inéditos cambios, la antropología es también —o debería ser-diagnosis de lo que ocurre en nuestra sociedad. Y aviso - si el diagnóstico resulta correcto- de lo que puede suceder en ella en el caso de que no cambiemos la dirección emprendida. Incluso —como ya señaló James Fernández (1999) y he recogido e intentado desarrollar en uno de mis últimos trabajos (Díaz G. Viana 2003: 179-205)_ quizá habría que recuperar, en este sentido, la antigua y sustancial función de la antropología en cuanto "proyecto humanizador. De trabajar sobre y por lo humano hacia el ayer, pero también hacia el futuro. Como Llobera también ha escrito:

La antropología no puede renunciar a la herencia de sus antepasados. Este es un honor y un reto que la disciplina debe aceptar con valentía. Esto implica, ante todo, que la antropología es un humanismo, es decir, que debe situar al ser humano, a la persona humana, como valor central y absoluto, al que debe subordinarse todo lo demás (Llobera 1990: 156).

Conocer, comprender y potenciar lo humano es nuestra última tarea. Y la etnoliteratura, como lectura y decodificación de la condición humana, una de las vías privilegiadas que la antropología pone a nuestra disposición para hacerlo: el estudio antropológico del hombre desde lo literario.

\section{BIBLIOGRAFÍA CITADA}

Augé, MarC. 1993. El genio del paganismo. Barcelona: Muchnik Editores.

BASCOM, WILliam. 1981. Contributions to Folkloristics. Meerut (India): Archana Publications.

BARLEY, Nigel. 1983. The Innocent Anthropologist. Notes from a Mud Hut. Londres: Penguin Books.

BURKE, PETER. 1981. Popular Culture in Earley Modern Europe. Nueva York: Harper \& Row.

BuXó, M.. Jesús. 1993: "Etnología”, en Ángel Aguirre Baztán (ed.), Diccionario temático de Antropología: 275-278. Barcelona: Editorial Boixareu Universitaria.

CARAmés LAGE, José L. 2004. "La poesía mito-poética en la poesía de Ted Hughes". Liceus. Centro virtual. Literaturas extranjeras 30: 1-5.

CARO BAROJA, JULIO. 1967. Lo que sabemos del folklore. Madrid: Gregorio del Toro.

- 1972. Los Baroja. Madrid: Taurus.

- 1979. Cuadernos de campo. Madrid. Turner-Ministerio de Cultura.

- y Emilio Temprano. 1985. Disquisiciones antropológicas. Madrid: Ediciones Istmo.

Clifford, JAMES y GeORGe E. MARCus (eds.). [1984] 1991. Retóricas de la antropología. Barcelona: Ediciones Júcar.

DíAZ G. ViANA, Luis. 1991. "Prólogo" (a la edición española), en James Clifford y George E. Marcus (eds.), Retóricas de la antropología: 9-19. Barcelona: Ediciones Júcar. 
- 1997. De lo propio extraño. Madrid-Oiartzun: Sendoa.

- (ed.). 2000. Palabras para el pueblo. Aproximación general a la Literatura de Cordel (Vol. I). Madrid: CSIC.

- 2003. "La aldea fantasma: Problemas en el estudio del folklore y la cultura popular contemporáneosn. Revista de Dialectologia y Tradiciones populares VIII, 1: 29-46.

- 2003. El regreso de los lobos. La respuesta de las culturas populares a la era de la globalización. Madrid: CSIC.

DONNER, FLORINDA. 1982. Shabono: A True Adventure in the Remote and Magical Hearth of South American Jungle. Nueva York: Laurel Books.

FERNÁNDEZ, JAMES W. 1999. "La antropología y el proyecto humanizador. Meditaciones 'extramuros' sobre el 'momento milenio', sus compromisos y sus desafíos: un ensayon. Ágora. Papeles de filosofía 2: 5-14.

FREEMAN, DEREK. 1983. Margaret Mead and Samoa: The Making and Unmaking of an Anthropological Myth. Cambridge, Massachusetts: Harvard University Press.

FREUD, SIGMUND [1913] 1968. Totem y tabú. Madrid: Alianza Editorial.

FUENTE LOMBO, MANUEL DE LA (ed.). 1994. Etnoliteratura. Un nuevo método de análisis en Antropología. Córdoba: Servicio de Publicaciones de la Universidad de Córdoba.

- y M. ${ }^{a}$ ÁNGeles HeRmOSILlA (eds.). 1997. Etnoliteratura: Una antropología de elo imaginario? Córdoba: Servicio de Publicaciones de la Universidad de Córdoba.

García, José Luis y AsCensión BARAÑANo (coords.). 2003. Culturas en contacto. Encuentros y desencuentros. Madrid: Ministerio de Educación, Cultura y Deporte.

GEERTZ, CliffoRd. 1989: El antropólogo como autor. Barcelona: Ediciones Paidós.

GramsCI, ANTONIO. 1974. Antología. Madrid: Siglo XXI.

HÉRIZ, ENRIQUe DE. 2004. Mentira. Barcelona: Edhasa.

JiMÉNEZ NúÑEZ, ALFREDO. 1994. "Fuentes y métodos de la antropología: Consideraciones un tanto críticas", en M. de la Fuente Lombo (ed.), Etnoliteratura. Un nuevo método de análisis en antropología: 9-49. Córdoba: Servicio de Publicaciones de la Universidad de Córdoba.

KuucKhohn, ClYDE. 1983. Antropología. México: Fondo de Cultura Económica.

LÉvi-STRAuSS, ClaUde. 1963. Structural Antbropology. Nueva York: Basic Books, Inc., Publishers.

- 1988. Tristes Trópicos. Barcelona: Paidós.

- 1994. Mirar, escuchar, leer. Madrid: Ediciones Siruela.

Lisón TOLOSANA, CARMELO. 1983: Antropología social y bermenéutica. Madrid: Fondo de Cultura Económica.

LORD, ALBERT. 1960. The singer of Tales. Cambridge, Massachusetts: Harvard University Press.

LLOBERA, JOSEP R. 1990. La identidad de la antropología. Barcelona: Ediciones Anagrama.

MEAD, MARGARET. [1928] 1984. Adolescencia, sexo y cultura en Samoa. Barcelona: Planeta-De Agostini.

- 1987. Experiencias personales y científicas de una antropóloga. Barcelona: Paidós.

ORTIZ GaRCía, CARMEN. 2001. "De los cráneos a las piedras. Arqueología y antropología en España, 1874-1977». Complutum 8: 273-292.

PINO DÍAZ, FERMín DEL. 1997. “Lectura contemporánea de textos proto-antropológicos, o propuesta modernizadora para editar crónicas de Indias", en Luis Díaz G. Viana y Matilde Fernández Montes (coords.), Entre la palabra y el texto. Problemas en la interpretación de fuentes orales y escritas: 143-187. Madrid-Oiartzun: CSICSendoa. 
PRATT, MARY LOUISE. [1984] 1991. "Trabajo de campo en lugares comunes", en Retóricas de la antropología: 61-90. Barcelona: Ediciones Júcar.

Propp, VlaDIMIR. 1984. Theory and History of Folklore. Minneapolis: University of Minnesota Press.

REDFIELD, ROBERT. 1960. "The Social Organization of Tradition", en The Little Community. Peasant Society and Culture. Chicago: The University of Chicago Press.

SAINT-EXUPÉRY, ANTOINE DE. 1979. El principito. México: Editores Mexicanos Unidos. SÁNCHEZ PIÑOL, ALBERT. 2004. La piel fría. Barcelona: Edhasa.

SAVATER, FERnANDO. 1992. "La deserción de los modernos". El País, Babelia (Revista de Cultura), 19-XII: 16.

TURNER, VICTOR W. y EDWARD M. BRUNER. 1986. The Anthropology of Experience. Urbana y Chicago: University of Illinois Press. 